Raimund Bleischwitz

Governance of sustainable development: co-evolution of corporate and political strategies

Originally published as:

Raimund Bleischwitz (2004):

Governance of sustainable development: co-evolution of corporate and political strategies

In: International Journal of Sustainable Development, 7, 1, 27-43 
Raimund Bleischwitz ${ }^{\mathrm{a},}$

\section{Governance of sustainable development: co-evolution of corporate and political strategies}

a Wuppertal Institute for Climate, Environment and Energy, Germany

* Corresponding author: Raimund Bleischwitz, Wuppertal Institute for Climate, Environment and Energy, Döppersberg 19, 42103 Wuppertal, Germany

E-mail: raimund.bleischwitz@wupperinst.org

Phone: +49-(0)202-2492-256

Fax: +49-(0)202-2492-108 


\title{
Governance of Sustainable Development: Co-Evolution of Corporate and Political Strategies
}

\author{
Raimund Bleischwitz \\ Wuppertal Institute, PO Box 100 480, D-42004 Wuppertal, Germany; Toyota Chair for Industry \\ and Sustainability at the College of Europe, Bruges, Belgium, E-Mail: \\ raimund.bleischwitz@wupperinst.org
}

Final Version, December 19, 2003, accepted for publication in: International Journal of Sustainable Development (Vol. 7/2004)

\begin{abstract}
The article proposes a policy framework for analysing corporate governance toward sustainable development. The aim is to set up a framework for analysing market evolution toward sustainability. In the first section, the paper briefly refers to recent theories about both market and government failures that express scepticism about the way framework conditions for market actors are set. For this reason, multi-layered governance structures seem advantageous if new solutions are to be developed in policy areas concerned with long-term change and stepwise internalisation of externalities. The paper introduces the principle of regulated self-regulation. With regard to corporate actors' interests, it presents recent insights from theories about the knowledge-based firm, where the creation of new knowledge is based on the absorption of societal views. The result is greater scope for the endogenous internalisation of externalities, which leads to a variety of new and different corporate strategies. Because governance has to set incentives for quite a diverse set of actors in their daily operations, the paper finally discusses innovation-inducing regulation. In both areas, regulated selfregulation and innovation-inducing regulation, corporate and political governance co-evolve. The paper concludes that these co-evolutionary mechanisms may assume some of the stabilising and orientating functions previously exercised by framing activities of the state. In such a view, the governments' main function is to facilitate learning processes, thus departing from the states' function as known from welfare economics.
\end{abstract}

Keywords: innovation-inducing regulation, knowledge creation, knowledgebased firm, market and government failures, regulated self-regulation 


\section{Introduction}

This paper starts from the assumption that governance toward sustainable development differs from conventional approaches of welfare economics (Hinterberger et al. 2000). Governance of sustainable development goes well beyond traditional, state-centred policy-making because it aims at pro-active changes of private actors' behaviours at different levels. It necessarily involves the lower levels of policy-making and private individuals active in policy formulation and implementation. Innovations generate positive externalities, enabling corporate actors to play a public role while doing good business on competitive markets. The notion of coevolution put forward in this paper not only accepts the pursuit of profit in emerging markets for sustainability, it identifies this pursuit as a driving force toward policy integration and the internalisation of some externalities. Motivated by selfinterest and soft incentives, corporate actors transform areas previously perceived as part of the public domain into markets for sustainable development. The state, however, retains the responsibility for structural conditions and innovationinducing regulations.

To test this assumption the article discusses the following questions:

- What exactly is the function of governance systems for sustainable development?

- How do systems of political and corporate governance differ and how do they interact?

- What are the characteristics of a system for developing synergies between political and corporate governance?

- Assuming that corporate players can play a public role, which conclusions can be drawn for policy makers? How does that affect the conception of the role of the state?

Methodologically, this paper refers to recent theories from both political science and economics. Political science analyses governance systems with less government (Héritier 2002; Majone 1998; Young 1999); economics offers findings on firms, market failures and regulatory theories (Williamson 1999; Nelson 2002; Stiglitz 2000). The interdisciplinary approach is worthwhile because political science, in particular what is known as actor-centred institutionalism, has a strong bond on administrations and policy-making. In analysing markets and firms, economics proves helpful, in particular the emerging branches of New Institutional Economics ${ }^{1}$ and Evolutionary Economics. The analytical framework derived from these theories to an extent departs from models of rational choice, i.e. it does not assume a fully rational actor with perfect information (Ostrom 1998; Mantzavinos 2002). Recent literature on corporate governance is of special relevance here as it provides insights into the motivation and self-interest of firms, which in turn is helpful for the design and reform of policies.

1 One reviewer sees new institutional economics much in line with the neoclassical approach. I will argue in the paper that more recent approaches reveal a shift, in particular regarding rationality and firms. 
Chapter 2 will give a short survey of theories about both market and government failures. It is proposed that both types of failure can be compensated by coevolution, i.e. by private actors assuming a public role and by governments providing appropriate incentives. Chapter 3 outlines some principles of governance as regulated self-regulation. Because co-evolution certainly goes beyond setting the frame, chapters 4,5 and 6 show in more detail how corporate actors, markets, and innovation-inducing regulatory tools emerge.

The present article fits well into a broader scope of ongoing policy research activities. The obvious reference is to the Johannesburg Summit 2002, which clearly addressed the need for public-private partnerships toward sustainability (Type II commitments). In analyzing a co-evolution between private and public rulemaking bodies, the ideas laid down here may especially fit for those regions where transnational and supra-international Corporate Social Responsibility (CSR) emerges and where reliable governments as well as organized civil societies' groups still have to come up. Our analytical framework seeks to provide a toolbox for evaluating these policies.

\section{Recent Theories on Market Failures and Government Failures - A Short Survey}

Markets are well known for being dynamic and powerful, but imperfect. Our short survey summarizes recent research results for categories of market failures that have been analysed extensively (e.g. Stiglitz 2000). To what extent do a) endogenous learning efforts allow to overcome failures and $b$ ) exogenous incentives enable compensation?

Market provision of public goods is difficult because their attributes of nonrivalry in use and non-excludability make production unattractive. This standard conceptualisation of public goods can however be problematic (Nelson 2002). Attributes may change due to technological progress; harbours and lighthouses illustrate such a conversion from a public to a private good due to technological improvements and better pricing possibilities. Though citizens are usually taken as one aggregated unit, they benefit from public goods in innumerable different ways. Preferences are often heterogeneous and change over time. The assumption of a fixed borderline between private and public goods no longer seems tenable; in fact, the borderline is rather blurry.

The notion of externalities also raises some questions. Internalisation efforts along Coase-type negotiations may come at the expense of third parties that have not been involved. Governments have to serve their respective voters and may tend toward making decisions in favour of certain vested interest groups. This might lead them to overlook vulnerable, little organized groups inside and outside society. Participation, which also has merits in other areas of sustainability, certainly becomes a topic in internalisation strategies. Its relevance becomes even clearer when we look at the openness of technological change (Freeman 1998; LeonardBarton 1995), where mechanisms for absorbing new knowledge are crucial. Acknowledging that firms pursue these interests of transforming knowledge into business concepts creates scope for an endogenous internalisation of externalities (Beckenbach 1998).

The category of adaptation deficits refers to the speed at which markets and firms adapt to new circumstances arising from new legislation and other exogenous 
factors. Evolutionary economics has shown that markets evolve step by step (Witt 2003; Pelikan/Wegner 2003), created by pioneers and early imitators from a variety of firms. Consumers are relevant in this process because their specific demands often starts vague and need to co-evolve with market development. The point here is that a typical market process evolves over time, driven by changing corporate behaviour as well as by stakeholder activities. Seen from this angle, incremental corporate change and stakeholder involvement become driving forces that are at least as important as the Schumpeterian entrepreneur.

Information deficits have also been the subject of extensive research in economics. What seems important for the present context is the necessary involvement of individuals and organisations in problem-solving efforts to balance information deficits. Though open or easy access to information may lower the costs of learning processes, the mere providing of information cannot replace real learning efforts. Knowledge creation depends not only on information supply, but alsoessentially-on individual and organisational learning.

Looking at market failures in general, the conclusion for governance structures is that to function properly, markets need participation and learning among and beyond market actors. If their efficiency is to be maintained and improved, markets need guidance and rules for stimulating participation and learning. Such guidance and rules can be provided by appropriate governance structures. The findings of Nobel laureates such as Douglass C. North (1990), Mancur Olson (1998), and Joseph Stiglitz (1998) would support this conclusion, which also fits in with the theories of New Institutional Economics and the German Ordnungspolitik. Beyond general statements, however, it seems that the real challenge is to stimulate continuous participation and learning processes rather than undertake heroic efforts and set an everlasting frame. After all, co-evolution of different actors and different rules may lead to better development processes than the traditional division of labour, where governments were supposed to determine the structural conditions and businesses to comply.

Recent theories on government failures have yielded similar findings. Beyond the often too simplistic general view of public choice theories, it makes sense to assume that self-interest is an important motivating factor for politicians and bureaucracies (Buchanan/Musgrave 1999). Moreover, regulatory agencies are exposed to the lobbying of powerful actors, which leads to the 'capture of the regulator' phenomenon. Clearly, control is the best check to self-interest and capturing endeavours. Such control may come from parliaments, competing parties, media, agencies for budget control, and civil society groups. Too much control, however, increases the regulatory costs and can seriously hamper innovations and learning.

Government failures put the development of both markets and society at risk by

- slowing down the dynamics of progress,

- causing high regulatory costs ('deadweight losses'),

- creating incentives for rent-seeking and lobbying activities that favour established interest groups against new businesses and SMEs,

- crowding out voluntary action and other non-paid civil activities; people rely on the government to take action and flinch from voluntary action even if public programmes turn out to be ineffective, 
- causing new externalities created by unforeseeable market responses to any regulation,

- causing cognitive overload due to dense regulation.

Ubiquitous knowledge deficits suggest a departure from rational choice approaches. No matter how extensive the competences pooled in their various administrative organizations, governments hardly possess the knowledge necessary to steer business and society in a certain direction. They can acquire new knowledge through hearings, studies, expert committees, and advisory councils. Nevertheless, there is no occasion for any general optimism about governments' steering capacities. Moreover, public budgets are loaded with huge deficits, so financial capacities are low. Governments depend heavily on the knowledge generated in the decentralized activities of research institutions, companies, and social bodies. Governments' comparative advantage in knowledge generation can rather be seen in terms of setting a tentative institutional frame, arriving at a consensus where conflicts among different groups arise, and formulating an overall orientation based on people's heterogeneous views. Overcoming knowledge deficits by acknowledging different roles and by accepting a division of labour in knowledge creation, thus, is a key to improving governments (Dror 2001; Stiglitz 1998; Rodrik 2000; Pelikan/Wegner 2003; Young 1999).

Our short survey on recent theorizing confirms that bad governments produce bad market outcomes, while good governments can improve market outcomes. Just as market failures are a stimulus to improving markets rather than giving up the whole idea of a market economy, government fallibility is no reason to give up regulatory policies. Two central government functions remain crucially important: governments guarantee certain structural conditions and counteract major market failures with severe negative impacts on society. Such endeavours are immensely complex. Market and government failures, therefore, call for a more comprehensive governance structure that actively involves corporate and societal actors. Such an involvement is not only necessary in terms of making the voices of interest groups and/or affected groups heard (which rational choice theorists suppose to be sufficient): It is fundamental in terms of knowledge creation. It is a permanent search for both market and policy improvements (Dror 2001). Analytical comprehensiveness requires an endogenous business element, which is often neglected in governance studies.

Against this background, a helpful approach clearly is to analyse a comprehensive governance structure as a co-evolving system able to learn over time. Criteria could be whether the system helps to control both markets and governments and enables companies as well as citizens to participate in markets. In this regard, the law is an essential aid to citizens and SME's in dealing with markets and governments (Nonet/Selznick 1978). The rule of law may serve, as we propose, an essential function for sustainable development, too. The following chapters will lay down further analytical steps in that direction.

\section{Governance as Regulated Self-Regulation}

Our notion of co-evolution starts from the proposition that markets and governments alike have a positive role to play in societies' development, not a negative one. These positive roles can be seen where markets provide goods and foster new technologies, and where governments guarantee the conditions for a fruitful and 
fulfilling life. Both functions are interrelated: markets rely on guidance and rules for which governments are indispensable; governments can only provide the context of a fruitful life if markets serve their function, too. At the same time, both players rely on civil society, whose positive role is obvious (also cf. Ahrens 2002).

Regulated self-regulation refers to these positive roles. A market economy relies on a wide array of both market-based and political institutions that perform stabilising, regulatory, and legitimising functions. Governance clearly takes place on multiple arenas, partly within and partly outside the scope of the state. It involves polycentric steering institutions (Héritier 2002; Young 1999) with a strong emphasis on subsidiarity, which has become prominent as a guiding principle of the EU's Amsterdam Treaty. Governments need to ensure that markets work properly within such an institutional frame and at the lowest possible transaction cost level. Seen from this angle, the traditional dichotomy between market and state, or between laissez-faire and intervention, loses importance. Market and state serve complementary functions that keep the system running. A well-performing market economy is a mixed composition of state and markets. Langlois and Robertson (1995) on business institutions, North (1990), Pelikan/Wegner (2003), and Rodrik (2000) formulate similar views.

According to Rodrik (2000), there are five basic types of market-supporting institutions that form a regulatory framework: property rights, macroeconomic stabilisation, social insurance, regulatory institutions, and conflict management. ${ }^{2}$ The latter refers to the necessity of arriving at a societal consensus when preferences change or unexpected events occur that demand a decision by society as a whole. It relates to the participatory capacities of a society. Concerned citizens participate e.g. through political referendums on individual issues (as in Switzerland), by being involved in public hearings ('voice option'), by acting collectively as consumers, by taking part in stakeholder consultations, by pooling financial power on the stock markets, and through their ability to control information provided by businesses. An econometric analysis across several countries by Rodrik (2000) reveals that participatory politics do enhance economic stability. It is worth underlining that such stability is defined in terms of resilience, i.e. the ability to adapt, and not in terms of sluggishness.

Let us take the example of sustainability targets to illustrate the co-evolutionary governance approach: The standard approach of welfare economics assumes a perfectly informed government able to set proper targets for the provision of public goods and for the internalisation of negative externalities. Such an approach is in evidence when Hinterberger et al (2000, p. 286) call for 'ecological guardrails.' Naïve market enthusiasts, in contrast, would claim that the forces of supply and demand do the job-targets would intervene in allocation efficiency and might not be needed at all. In distinction to both welfare economics and market enthusiasts, the governance approach this paper puts forward makes target formulation a coevolutionary process rather than a one-time shot. Targets are relevant because businesses need to widen their set of choices; they have to readjust their expectations in order to search for a new direction of innovations. People also need to reconsider their habits; they rely on communication in order to take other views into account. Targets, hence, need to be made consistent among different policy sectors in order to improve overall clarity. In this sense, we propose that an ecoefficiency increase by a Factor Four can serve as a strategic open target, able to be translated to the individual level of decision-making and, at the same time, serving

2 This is very similar to the German Ordnungspolitik; see also Ahrens (2002). 
as a goal for development without being fixed to a narrow schedule (Weizsäcker et al. 1997; Bleischwitz 2003b). The legally binding character of such target formulation, thus, can evolve over time.

Our co-evolutionary view stresses the importance of knowledge generation in different actor groups. Managing more complex structures of public goods and externalities, such as biological diversity and different land use functions, requires decentralized processes of knowledge creation, bringing forward a variety of targets within the relevant regions and means to implement them. From a policy perspective, topics emerging throughout these decentralized processes can be picked up later on when the need for coordination or harmonization arises. That might happen, for example, with measurement methodologies and performance indicators. At a later stage in policy cycles policy-makers will already rely on the practical experience of pioneers and early imitators. Their experience allows setting either more ambitious and/or legally binding targets. Co-evolution, thus, is in no contradiction to ambitious policies. By emphasizing knowledge generation over time, the approach differs from other approaches that define sustainability in terms of departing from un-sustainability (Wilkinson/Cary 2002, p. 383). Our governance proposition is that, whatever the teething problems, formulating sustainability targets endorses individual and organisational efforts to achieve clarity, which is a necessary prerequisite for re-orientation toward sustainability. Regulated self-regulation can be seen as an on-and-off connection between political and corporate activities, where different stages of progress can emerge over time. Policy integration, as proposed inter alia by the EU's Cardiff process, takes place on multiple arenas, including firms and markets. This co-evolution of corporate and political governance, is the basis for the elements of our analytical policy framework discussed below (also see Figure 3).

\section{Governance and Knowledge-Based Firms}

But how does the notion of profit-maximizing firms fit into such a policy framework? This is perhaps the blind spot of governance approaches rooted in the political sciences. ${ }^{3}$ Would profit-maximising firms not try to escape responsibility because of its inherent costs, and continue to act as free riders benefiting from action taken by others? This might well be the case. Corporate behaviour is unlikely ever to become benevolent for society as a whole or for the global commons. Why should it? But companies can play a public role by overcoming traditional profitmaximizing behaviour while doing good business in competitive markets. Corporate actors create new markets for sustainable development that have previously been perceived as part of the public domain. The following remarks and the subsequent chapter explain why.

Recent economics (Nelson 2002) reveals a shift in the connotation of 'profit maximisation.' Previously businesses were quite naturally assumed to be motivated by profits and striving toward optimisation along a sharply defined set of opportunities. Firms were not thought of as groping, experimenting and gradually innovating toward incremental improvements. The idea much rather was that the predefined set of average total cost, marginal revenues due to market demand, and technological choices predetermined profits. Management in this view aimed at an optimisation toward market equilibrium. Such companies would obviously have no interest in providing for common goods or internalising externalities.

3 The outstanding and admirable research of Elinor Ostrom nevertheless shows how corporate behaviour tends to be neglected in large parts of governance research. 
This model, however, could not account for the dynamics of competition and knowledge generation. More recent views therefore established an analytical model of knowledge-based firms (Leonard-Barton 1995; Langlois/Robertson 1995; Grant 1996; Nonaka/Toyama 2002). Firms are assumed to act under uncertainties and information deficits. They rely on permanent knowledge generation provided by outside sources, experiments, and internal implementation processes. Firms can also create markets from scratch, by coordinating with others along vertical or horizontal lines. In doing so, firms establish communication with stakeholders in order to learn about changing demand, developing useful goods and services, and in order to avoid stunning blows of hostile reaction. Figure 1 illustrates that firms make use of a spiral of knowledge generation helping them to transform information generated elsewhere into useful knowledge and, moreover, into transaction cost-reducing routine.

\section{Fig. 1: The spiral of knowledge generation}

The question now is whether such a model overcomes prevailing assumptions about corporate approaches to sustainable development and involvement in governance structures. What are the implications for the questions outlined here if the model is acknowledged to reflect competitive markets? Keys to an answer are a) our proposition that there is no fixed borderline between common and private goods and b) that there are potential low-cost or even profitable options ('lowhanging fruit'). Knowledge-based firms basically do two things toward sustainable development while serving their own interest: They develop technologies and/or services that are private but contribute to public goals. Renewable energies and clean water technologies are just a few examples. Firms also work on demand creation, be it by marketing or other professional forms of doing business. Examples are services like leasing, renting, pooling, and sharing goods that contribute to the commons, such as the organisation of car-sharing by the industry in order to save costs for parking space. Moreover, firms in their internal processes can switch to integrated management and value chain management. These efforts help combat free riding. Sustainable business models have been developed by Hart (1995) and Altman (2001); v. Dijken et al. (1999), Gabel/Sinclair-Desgagné (1998), and Porter/v.d. Linde (2000) also deal with such analytical models. Important to note, these researchers do not yet explore the blurry borderline between public and private goods, a proposition whose acknowledgement would give additional motivation for change.

A point that is relevant in the context of co-evolution is that firms participating with stakeholders in the evolution of new market rules can profit from that exercise. This is not only because they can influence the outcome. The main reason, once again, is the learning advantage of being a forerunner or fast imitator. Adaptation time are significantly shorter for participating firms. Learning during times of governmental reframing can trigger competitive advantages. In other cases, any further regulation has to rely on experiences gained by pioneering firms because they can draw on precise data about the costs and benefits of various institutional mechanisms. Governance systems, thus, can rely on exploration and experiments undertaken by corporate actors. The free-riding position of simply waiting for market rules to come because of the costs of their development is only one choice for firms.

Transnational companies (TNC's) such as chemical giant BASF or the oil companies BP and Shell illustrate how firms act within our policy framework. Formerly devoted to 'dirty' business and looking back on a long tradition of environmental pollution, such firms have started to learn from failures. Sometimes painful (as in 
the case of Shell versus Greenpeace over the Brent Spar oil platform in the North Sea, or the condemnation of BASF for tardiness in developing CFC substitutes), sometimes deliberate (as in the case of BASF development of eco-efficiency schemes), sometimes fundamental (as in the change of core competences toward renewable energies): These companies now create new markets that relieve environmental pressure and act as knowledge-based firms, combining the valueadding activities of manufacturing and services. They also communicate intensively with stakeholders from various societal groups. Moreover, TNCs may be able to assume rule-making authority in societies where the law and the state can be considered weak (Cashore 2002; Haufler 2001: p. 120ff.).

It is worth noting that not only TNC's but also small and medium-sized enterprises (SMEs) can act as knowledge-based firms. Some theories (Langlois/Robertson 1995) even suggest that SME networks (like Silicon Valley) have more innovative thrust than the big companies so advantageous from the Schumpeterian view. Such networks among SMEs are quite often associated to local or regional clusters of innovation, involving local municipalities, universities, etc. In a wider horizon its relevance for market development and stakeholder concerns mean that innovative business increasingly requires understanding local issues beyond the regional or national borders. Figure 2 shows a firm as part of a social environment, interacting with numerous outside stakeholders.

\section{Fig. 2: Firms as parts of social environments}

Corporate governance is an issue that also fits well into an analysis of how firms learn and how they can be managed in a consistent way (Williamson 1999). The concept is of increasing importance in the business community. It addresses all kinds of management tools able to steer a complex company in uncertain markets in co-operation with shareholders and stakeholders on the basis of legal regulations and market-based guidelines. With its emphasis on responsibility, corporate governance restricts behaviour seeking for any profit possible and prevents businesses from undertaking high-risk activities at the expense of society. In addition, it supports firms in creating new knowledge helpful for solving future complex problems: today's ideas and institutions shape tomorrow's markets.

The conclusion for an analytical policy framework is not that the model of the knowledge-based firm reflects the only or dominant form of doing business. Many firms struggle to survive and hardly spend time with learning and exploring new opportunities. Though they may be seen as laggards, they are still relevant for an analysis. One also has to keep in mind that firms do not necessarily act with total consistency. Some operations may become more sustainable than others where asset-specific investments hinder rapid change. But we would like to suggest that firms tend to imitate pioneers and successors through benchmarking processes, so that incentives for improvements are easier to understand if they also come from markets, and not only from governments or the law. These processes of imitation lead to a horizontal diffusion of best practices, which is pivotal for sustainable development (see Figure 3 below).

Our analytical framework has strong roots in both empirical and theoretical research. The driving force for change is a capitalist knowledge-based firm, and not only the ethically inspired entrepreneur or a marketing department determined to establish a clean reputation. Knowledge-based firms act as entrepreneurs and pioneers, they galvanize other companies and markets. Along that path, a governance structure will have to foresee mechanisms that keep an eye on the overall process of change, including the firms preferring externalisation. 


\section{Markets for Sustainability}

The thesis outlined above about a public role for corporate actors not only proposes 'better' firms but also 'better' markets. It may come as a surprise that larger markets for sustainability are emerging beyond a few pioneering firms. Contrary to Lux (2003), the profit motive seems to entail more sustainability potential than sceptics perceive. The proof, thus, is related to the evolution of markets. They evolve over time and with institutional and behavioural change effected through appropriate governance structures. Rigid frameworks, however, are not conducive to change, which requires flexible structures.

Technological change has a definite bearing on market evolution (Freeman 1998; Langlois/Robertson 1995). Discoveries can set the course for cleaner production, more efficient manufacturing processes, new products able to lower environmental pressure, etc. One may underline that technological change can shift the borderline from public goods toward private goods insofar as goods formerly perceived as public can be provided by private action. A clean environment, seen from this angle, can at least partly be provided through private market activities. Firms hold an interest in these emerging markets as long as profit can be expected. Sequences of incremental technological change can stimulate markets at least as well as radical innovations can-incremental changes are more open to flexible incentives provided by other firms, stakeholders, and regulatory efforts.

Transaction costs associated with research and development as well as with the ensuing establishment of new markets of course have to be taken into account. Markets for public goods involve a multitude of actors. Of some public goods, consumers have only a vague notion so their demand needs to be awakened (Loasby 2001). Firms, markets, and institutions can economize these transaction costs. Seen within the analytical framework outlined here, the process is one where originally public activities gradually move toward the involvement of profitable markets. The essential prerequisite are co-evolving incentives set through governance systems, a point that deserves more thorough research. ${ }^{4}$ Agencies and standardized business reports offer ways of lowering transaction costs. In terms of market evolution, the following steps can be expected to lower transaction costs:

- overcoming information deficits,

- overhauling sustainability management within firms,

- establishing supply chain management among firms (vertical cooperation),

- opening the supply chain for stakeholder involvement,

- initiating sequences of incremental innovations or more radical innovations like functional redesign or system renewal,

- promoting horizontal diffusion of innovations.

Emerging markets for sustainability are especially obvious in some areas. Of course eco-efficiency is about new markets for clean technologies and services. The same holds true for energy efficiency and clean energy supply. But how does

4 See from our list of references Bleischwitz $(2003 a+b)$; Cashore (2002); v. Dijken et al. (1999); Gabel/Sinclair-Desgagné (1998); Haufler (2001); Héritier (2002); Weizsäcker et al. (1997). 
this apply with other environmental problems such as climate protection? Is the climate not a truly global public good? This paper does not seek to argue against open access to and non-rivalry in consumption of Earth's atmosphere. But the proposed thesis about markets for sustainability may open a new perspective on the problem of non-excludability. Climate protection comes with energy efficiency, with increasing shares of renewable energies, and with growing markets for eco-efficiency as a substitute for resource-intensive manufacturing processes. These markets can be made profitable; marginal cost functions can be modelled as step-shaped functions. Emerging stepwise along a learning governance structure, sustainability markets also produce positive externalities insofar as they have positive impacts on Earth's atmosphere. Seen from this angle, governance for sustainable development becomes a positive-sum game: once markets for energy efficiency, renewable energies, and eco-efficiency start to emerge, they can provide public goods or, more precisely, reduce risks and contribute to stabilizing Earth's atmosphere. Working toward the realization of such a scenario requires strengthening processes of search, discovery, innovation, and diffusion. This is a definite challenge for firms, stakeholders, and governments. Figure 2 (above) illustrates the double meaning of environment: firms act as parts of natural and social environments alike. Markets for sustainability emerge as a means for solving coordination problems among different actors where goods need to be provided.

\section{Innovation-Inducing and Responsive Regulation}

As outlined above, any governance of sustainability will have to deal with manifold forms of doing business as well as with the day-to-day policies of a wide variety of actors. Of course there is room for command-and-control approaches and other policies that restrict businesses in case of permanent non-compliance or high-risk activities. But governance structures also become important when longterm tasks like climate protection are to be performed, which requires learning and change. For such tasks, the notion of innovation-inducing regulation (Jänicke/Jacob 2002) fits into our framework. This type of regulation is not only conducive to innovation but also co-evolves along with the specific developments in each case. Such co-evolution between corporate and political actors is based on the insight that important governance functions have to be dealt with at the level of day-to-day governance and cannot completely be regulated ex-ante by any political or constitutional order. This is because of uncertainties, knowledge deficits and, by and large, the creativity of the human mind in performing actions with unpredictable results. One may note that these uncertainties derive from different sources: the exploration of the previously unknown as well as the persistence of market failures that prove more difficult to overcome than expected. Innovationinducing regulation, hence, co-evolves with corporate activities and the emergence of new markets for sustainability. In contrast to Jänicke and Jacob (2002), who put great emphasis on political actors, we would argue the strength of coevolution as a process. This statement on co-evolution is stronger than the analysis of Jänicke and Jacob (2002) reveals, who put more emphasis on political actors.

Innovation-inducing regulation has a short time horizon of a few months or years, whereas framing efforts have an impact over many years if not decades. Innovation-inducing regulation relates to the governmental function of absorbing societal problems, bringing together heterogeneous actors, arriving at solutions for specific problems. At the same time, this type of regulation takes into account that governments do not necessarily have the knowledge what exactly can be done. They draw business attention to certain problems rather than telling them what to do. 
Governments help to establish win-win coalitions, but they do not specify which action should be taken. They participate in networks and other forms of multiactor coalitions without being in a dominant position. Policy-making shifts from policy-makers to a multitude of actors including corporate actors and environmental and/or social NGOs. Corporate governance and our notion of knowledge-based firms fit well into a comprehensive governance system.

Figure 3 illustrates this view. It basically shows that policies and management develop through different stages, moving from immediate problem-solving to institutionalisation to low-cost, innovative, and preventive approaches. The point for governance is twofold: Firstly, each stage serves a certain function, and any institutional leapfrogging strategy may come at the expense of comprehensiveness and major actors. Secondly, any progress depends on co-evolution, not only on success in policy or management. There is hardly a country in the world where ecoefficient services (stage 4 in environmental management in the figure below) emerge without incentives being set by governments nor, vice versa, where horizontal coordination among ministries and institutional adaptation flexibility (stages 3 and 4 in environmental policy) improve without support from vested or newly-established interest groups.

\section{Fig. 3: Co-Evolution of Corporate and Political Governance}

The figure suggests that participatory and administrative processes in both governments and businesses increasingly fulfil important governance functions previously devoted to a political framework. Stabilization, for instance, not only results from a framework but also from adaptation to new conditions. The importance of adaptive flexibility increases with the degree of uncertainty and change. For governance aiming at long-term change with varied innovation, adaptive flexibility is therefore at least as relevant as an ex-ante framework. This is also why empirical research on actor behaviour is so important.

Responsive regulation as defined by Ayres and Braithwaite (1992) and Nonet and Salznick (1978) is a helpful concept for describing processes between actors where participation creates regulatory knowledge at different levels. It refers to the leeway that corporate actors need in order to innovate, and which governments should guarantee. In addition, it emphasizes the need to strengthen third parties such as environmental NGOs in their capacity to monitor progress and articulate concerns. The concept of governance for sustainable development can draw on these recent theories on innovation induced by soft regulation and achieved in multi-actor coalitions.

What does that mean for a comprehensive governance strategy? The purpose of innovation-inducing and responsible regulation is to enable action at the microlevel of markets and society by accepting diversity in actor behaviour and by giving appropriately flexible incentives. This implies a kind of regulation not determined by a rigid frame, and precludes strict regulation that would stifle the adaptive flexibility of markets and societies. The following criteria are geared to assessing to what extent regulatory policies stimulate learning processes among actor groups:

1) Does the regulation reflect the total cost of an activity and does it facilitate price mechanisms (i.e. the ability of prices to change according to supply and demand)? 
2) Does the regulation state its targets clearly and thus provide orientation for actors in the market and society, enabling them to adopt similar targets and related measures?

3) Does the regulation allow for adaptive flexibility and freedom to choose among different alternatives?

4) What kind of incentives for knowledge creation are given?

5) Are there inconsistencies in the regulation or in relation to other institutions that permit bypassing the rules?

6) Are there incentives for third actors to become partners in implementing and improving the regulation?

Case studies on how such criteria and the resulting policy framework can be applied have been published on Japanese sustainability approaches and on German waste policy (Bleischwitz $2003 \mathrm{a}+\mathrm{b}$ ). An ongoing study (see acknowledgements) will discuss further case studies that cover local and regional approaches as well as international areas. The upcoming EU strategies on Integrated Product Policy and on Sustainable Use of Natural Resources also rely on corporate strategies and may provide excellent points of departure for further case studies.

\section{Conclusions}

Governance as described in the present paper reveals its greatest strengths where long-term innovatory tasks with low immediate damage potential are pursued. Such processes usually result in new actor coalitions and the formulation of new rules of the game. Areas of application are climate change policies (beyond the need for managing specific impacts), eco-efficiency policies, water policies, provision of public goods, etc. Where governance approaches might fall short is in dealing with immediate concerns and specifically vulnerable groups in societies worldwide. But nevertheless it is likely that multi-actor and multi-layered governance systems will become more important within the next years.

In distinction to many other approaches, our policy framework welcomes the selfinterest of business as a beneficent force. Business self-interest is not content with the exploitation of 'low-hanging fruits' but promotes the creation of new knowledge as businesses recognize changing market expectations and the resulting needs for market evolution. A cloud on this horizon is, however, that if profits fall short of expectation, business can always opt out of governance processes. The function of governance, thus, is to support processes of mutual learning, with governments in a strong but not dominant position. This function goes well beyond the usual compliance procedures.

Innovation-inducing regulation levels the playing field for corporate actors in their daily operations, leaving it up to society and markets to determine which solutions are discovered and how they are implemented. The provision of common goods and the internalisation of externalities, usually thought of as core competences of states, can gradually shift to co-evolutionary processes managed by corporate, societal, and governmental action. Though existing programmes of privatisation do have some shortcomings, the general indication is that actors learn from mistakes, and that further involvement of corporate and other societal actors is likely to improve governance processes. Monitoring remains a public task, as does the provision and maintenance of a legal order that is able to deal with free riders and serious non-compliance. 
In analytical terms, our policy framework for corporate action combines elements of new institutional economics, evolutionary economics, and actor-centred institutionalism. Though each of these branches has been criticised for being heterogeneous and much in line with traditional approaches shown to be 'unsustainable,' the overall framework seems consistent and well suited for application in case studies.

\section{Acknowledgements}

This paper has benefited much from a grant provided by the Japanese Economic and Social Research Institute (ESRI), channelled through the Mitsubishi Research Institute and the Nomura Research Institute as part of the Millennium Collaboration Projects. I owe special thanks to my WI colleagues Peter Hennicke, Michael Kuhndt, Holger Wallbaum, Thomas Langrock, as well as to Kilian Bizer, Carlo Carraro, Frank Convery, Matthias Finger, Hans Nutzinger, Peter Weise, Taishi Sugiyama and two anonymous referees. Nina Hausmann was instructive in language editing.

\section{References}

Ahrens, J. (2002) Governance and Economic Development. A Comparative Institutional Approach, Cheltenham / Northampton (Edward Elgar).

Altmann, M. (2001) 'When green isn't mean: Economic theory and the heuristics of the impact of environmental regulations on competitiveness and opportunity cost', Ecological Economics, Vol. 36, Issue 1, pp. $31-44$.

Ayres, I. / Braithwaite, J. (1992) Responsive Regulation. Transcending the Deregulation Debate, Oxford (Oxford University Press).

Beckenbach, F. (1998), 'Socio-technological innovation and sustainability', in Faucheux, S. et al. (eds) Sustainability and Firms. Technological Change and the Changing Regulatory Environment”, Cheltenham/Northapmton (Edward Elgar), pp. 99 - 129.

Bleischwitz, R. (2003a) 'Governance of eco-efficiency in Japan - an institutional approach', in Internationales Asienforum / International Asian Quarterly, Vol. 34, No. 1-2, pp. 107 126.

Bleischwitz, R. (2003b) 'Cognitive and institutional perspectives of eco-efficiency', Ecological Economics, Vol. 46, pp. 453 - 467.

Buchanan, J. M.; Musgrave, R. A. (1999) Public Finance and Public Choice. Two Contrasting Visions of the State, Cambridge; London (MIT Press).

Cashore, B. (2002) 'Legitimacy and the privatization of environmental governance: How NonState Market-Driven (NSMD) governance systems gain rule-making authority', Governance: An International Journal of Policy, Administrations, and Institutions, Vol. 15 , No. 4, pp. $503-529$.

v. Dijken, K. et al. (eds.) (1999) Adoption of Environmental Innovations. The Dynamics of Innovation as Interplay between Business Competence, Environmental Orientation and Newtork Involvement, Dordrecht (Kluwer).

Dror, Y. (2001) The Capacity to Govern. A Report to the Club of Rome.

Freeman, C. (1998) The economics of technical change, in Archibugie, D.; Michie, J. (Eds.), Trade, Growth and Technical Change, Cambridge, pp. 16 - 54. 
Gabel, H.L. / Sinclair-Desgagné, B. (1998) 'The firm, its routines and the environment', in: Tietenberg, T. / Folmer, H. (Hg.), The International Yearbook of Environmental and Resource Economics 1998/99, Cheltenham/Northampton (Edward Elgar), pp. 89 - 118.

Grant, R. M. (1996) 'Toward a knowledge-based theory of the firm', Strategic Management Journal Vol. 17, Special Issue (Winter), pp. 109-122.

Hart, S.L. (1995) 'A natural-resource based view of the firm', Academy of Management Review, Vol. 20, No. 4, pp. $996-1014$.

Haufler, V. (2001) A Public Role for the Private Sector. Industry Self-Regulation in a Global Economy, Washington D.C. (Carnegie Endowment).

Héritier, A. (Ed.) (2002) Common Goods. Reinventing European and International Governance, London et al. (Rowman \& Littlefield Publ.)

Hinterberger, F. / Luks, F. / Stewen, M. / v.d.Straaten, J. (2000) 'Environmental policy in a complex world', International Journal of Sustainable Development, Vol. 3, No. 3, pp. $276-296$.

Jänicke, M. / Jacob, K. (2002) 'Ecological modernization and the creation of lead markets', in $F U$ Berlin, FFU rep 03/2002.

Langlois, R. N.; Robertson, P. L. (1995) Firms, Markets, and Economic Change: A Dynamic Theory of Business Institutions, London (Routledge).

Leonard-Barton, D. (1995) Wellsprings of Knowledge: Building and Sustaining the Sources of Innovation, Boston (Harvard Business School Press).

Loasby, B. (2001) 'Cognition, imagination and institutions in demand creation', Journal of Evolutionary Economics Vol. 11, pp. 7 - 21.

Lux, K. (2003) 'The failure of the profit motive', Ecological Economics, Vol 44, No. 1, pp. 1 - 10.

Majone, G. (1998) 'From the positive to the regulatory state: causes and consequences of changes in the mode of governance', Journal of Public Policy, Vol. 17, Part 2, pp. $139-167$.

Mantzavinos, C., Individuals, Institutions, and Markets, Cambridge MA (Cambridge University Press) 2001.

Nelson, R. (2002) 'The problem of market bias in modern capitalist economies', Industrial and Corporate Change, Vol. 11, No. 2, pp. 207 - 244.

Nonaka, I.; Toyama, R. (2002) 'A firm as a dialectical being: towards a dynamic theory of a firm', Industrial and Corporate Change, Vol. 11, No. 5, pp. 995 - 1009.

Nonet, Ph.; Selznick, Ph. (1978): Law and Society in Transition - Towards Responsive Law, New York (Harper \& Row).

North, D.C. (1990) Institutions, Institutional Change and Economic Performance, Cambridge.

Olson, M. (1996) 'Big bills left on the sidewalk: why some nations are rich, and others poor', Journal of Economic Perspectives, Vol. 10, No. 2, pp. 3 - 24.

Ostrom, E. (1998) 'A behavioural approach to the rational choice theory of collective action', American Political Science Review, Vol. 92, No. 1, pp. 1 - 22.

Ostrom, E. (2000) 'Collective action and the evolution of social norms', Journal of Economic Perspectives, Vol. 14, No. 3, pp. $137-158$.

Pelikan, P. / Wegner, G. (Eds.) (2003) The Evolutionary Analysis of Economic Policy, Cheltenham / Northampton (Edward Elgar).

Porter, M.; Linde, C.v.d. (2000) 'Green and competitive: ending the stalemate', in E.F.M. Wubben (Editor): The Dynamics of the Eco-Efficient Economy, Cheltenham/Northampton (Edward Elgar), pp. 33-55.

Rodrik, D. (2000) 'Institutions for high-quality growth: What they are and how to acquire them', Studies in Comparative International Development, Fall 2000, Vol. 35, No. 3, pp. 3 - 31.

Stiglitz, J. (1998) 'The private use of public interests: Incentives and institutions', Journal of Economic Perspectives Vol. 12 (2), pp. 3 - 21.

Stiglitz, J. $\left(2000^{3}\right)$ Economics of the Public Sector, New York; London (Norton \& Company).

Weizsäcker, E.U.; Lovins, A.; Lovins, H. (1997): Factor Four: Doubling Wealth - Halving Resource Use, London (Earthscan). 
Williamson, O.E. (1999) 'Strategy research: governance and competence perspectives', Strategic Management Journal, Vol. 20, H. 12, pp. 1087 - 1108.

Young, O. (1999): Governance in World Affairs, Ithaca and London (Cornell University Press).

Wilkinson, R. / Cary, J. (2002): Sustainability as an Evolutionary Process. International Journal of Sustainable Development, Vol. 5, No. 4, pp. $381-390$.

Witt, U. (2003) The Evolving Economy: Essays on the Evolutionary Approach to Economics, Cheltenham/Northampton (Edward Elgar). 
Fig. 1: The spiral of knowledge generation

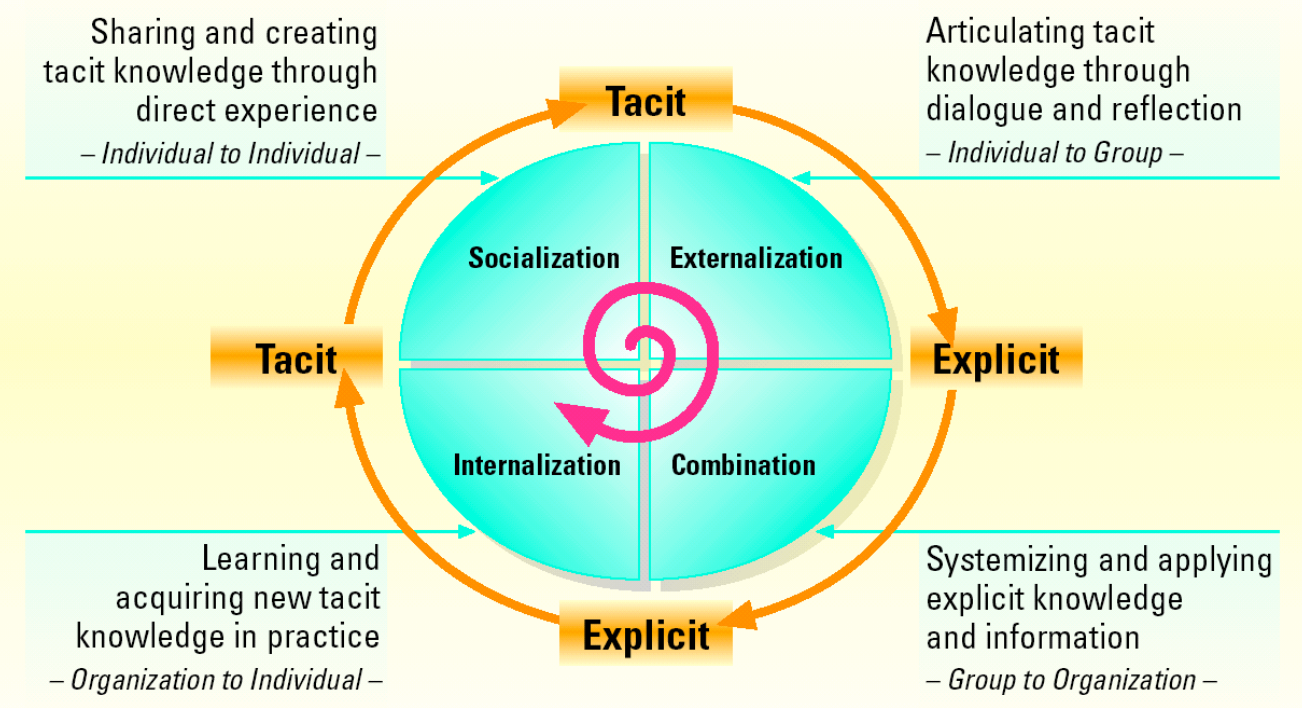

Source: Nonaka/Toyama 2002. 
Fig. 2: Firms as parts of social environments

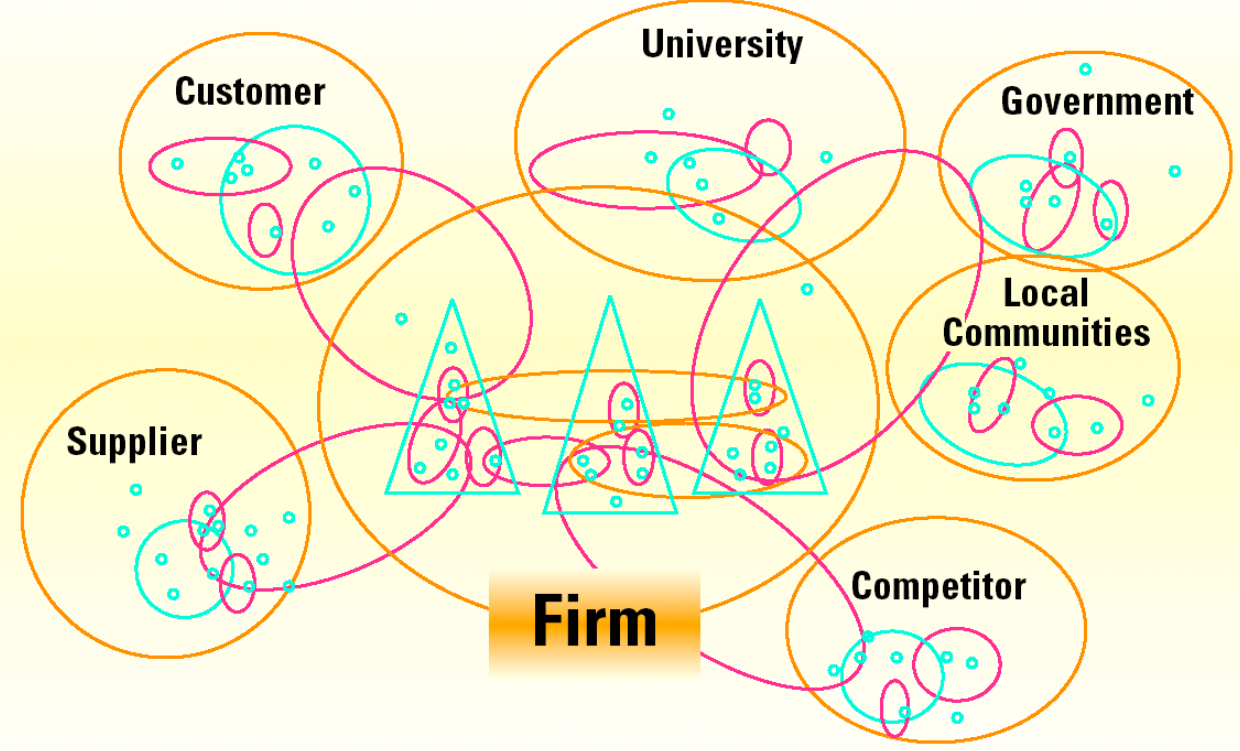

Source: Nonaka/Toyama 2002. 
Fig. 3: Co-Evolution of Corporate and Political Governance

Policy and management development

4 Efficient institutions with adaptation flexibility

3 Horizontal coordination among ministries, new framework

2 Environmental ministries

1 Weak and isolated agency

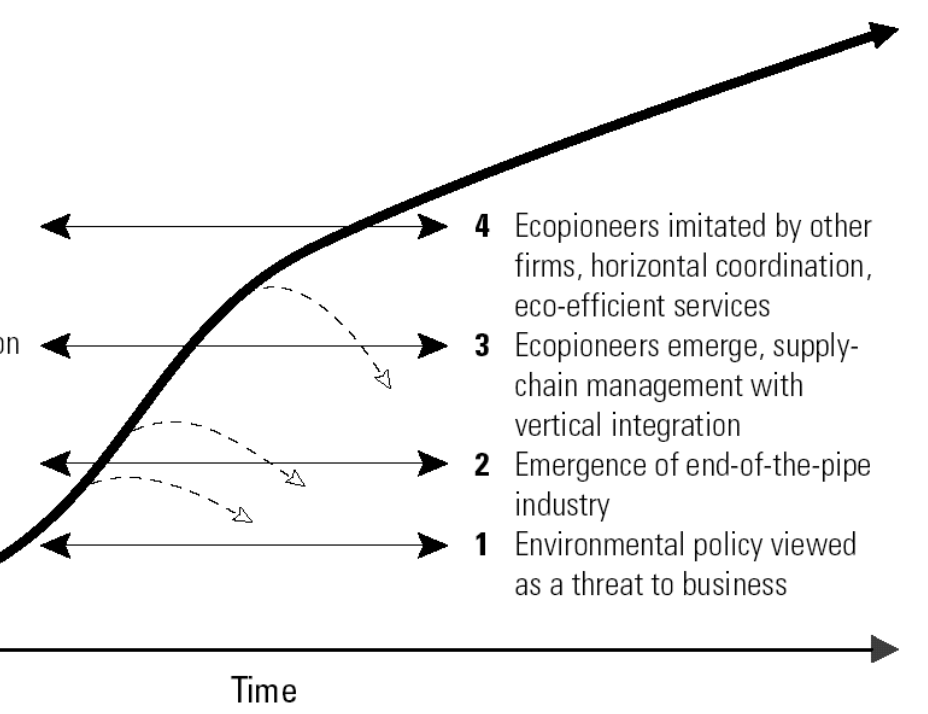

Own compilation

Source: Bleischwitz 2003a. 